\title{
Archaeology and Contemporary Art: An experiment of virtual stratigraphy
}

\author{
Peirui Yang \\ Área de Prehistoria, Universidad de \\ Alcalá, Alcalá de Henares (Madrid), \\ Spain \\ peirui.yang@edu.uah.es
}

\section{INTRODUCTION}

This research and artistic practice mainly form the concept of virtual stratigraphy through the extension of the concept of archaeology, and establishes the research framework of archaeology and contemporary art, such as philosophy, media theory, etc. The creation of digital art and sound art on the basis of theoretical research has finally formed the virtual stratigraphy series.

In recent years, exhibitions related to archaeology and contemporary art have continued to appear, and artists have continued to use various concepts of archaeology for artistic creation. In the field of traditional archaeology, art research is also an important part. The trend of contemporary archaeology is multi-dimensional, and the themes of archaeology and contemporary art are constantly evolving. Archaeologists and artists are gradually participating in this dialogue.

In this context, I combine theoretical research with artistic practice, and use Practice-led Research in the field of art. I formed my own artistic practice through the concept of "extension" of theory, and created a series of virtual stratigraphy, which is based on contemporary temporality and archaeology.

\section{THE THEORETICAL FRAMEWORK OF ARCHAEOLOGY AND CONTEMPORARY ART}

In this research, I hope to combine the academic structure with the characteristics of artistic practice. More precisely, this is an academic attempt to explore artistic practice from the perspective of research methodology. I hope to propose a specific framework for this work, because contemporary art and archaeology have not yet conducted a complete academic study, but the links between them are scattered. In fact, contemporary art should not establish a paradigm, but from the perspective of academic research, we still need a specific way to better understand the connection between the two, so we will conduct research in this way.

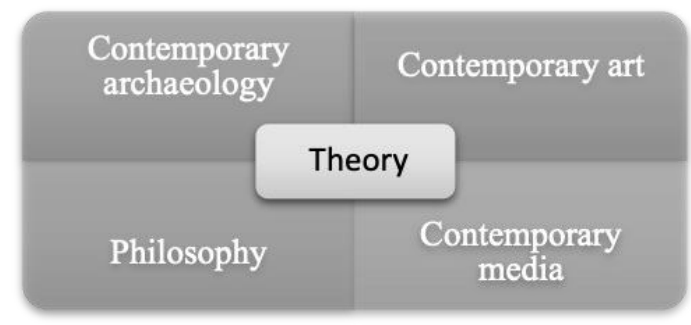

Figure 1: Archaeology and contemporary art theory research (by author)

Archaeology itself is an activity that goes from text to excavation, but the text as a basis has led us to think about archaeology and then we need to check if it has other meanings. Reading the text is like an excavation activity and staying in the text is stop. We have already talked about archaeological routes. The routes must be open, not necessarily valid routes, but trying is the most important thing. So, we have to try to clarify the philosophical turn of contemporary archaeology.

Starting from The Archaeology of Knowledge (Foucault, 1969), Michel Foucault proposed an archaeology of knowledge and philosophy. Archaeology today is more about the origin of ourselves and our society. (Renfrew \& Bahn 2013). The road represents a kind of turn, because the philosophical turn extends along the way. After Michel Foucault archaeology has been discussed more in the field of philosophy, especially in the concept of him, not the basic concept, but as an expanded one. "Extend" is a very important concept here. We must point out the important role of "extension" in the philosophical turn of contemporary archaeology. 


\section{ARTISTIC PRACTICE OF VIRTUAL STRATIGRAPHY}

"The proper approach for philosophical humanism is not to abandon the problem of knowledge, which has long been the main theme of the philosophical tradition." (Rockmore 1999, p.81).

Concepts are usually the main core of my artistic practice. However, the existence of the concept itself, in my opinion, is a philosophy, a thing based on language and superior to behaviour. I have cited some philosophies and theories of conceptual art. The purpose is to make my artistic practice and my work purer. But there is a problem here is that there is a paradox between "existentialism" and "nonexistentialism", because experimental music and sound art exist under the nature of immediacy. Deleuze and Guattari properly.
1. stratification
2. assemblages
3. rhizome
4. plane of consistency
5. deterritorialisation
6. abstract machines"
(Buchanan \& Swiboda 2006, p. 6)

"(...) This is schizoanalysis in a nutshell. With this in hand, we can now turn to six concepts I said we need to get a handle on to understand

In the theoretical part I have clarified the conceptual extension of archaeology, based on the "philosophical" and the "non-philosophical".

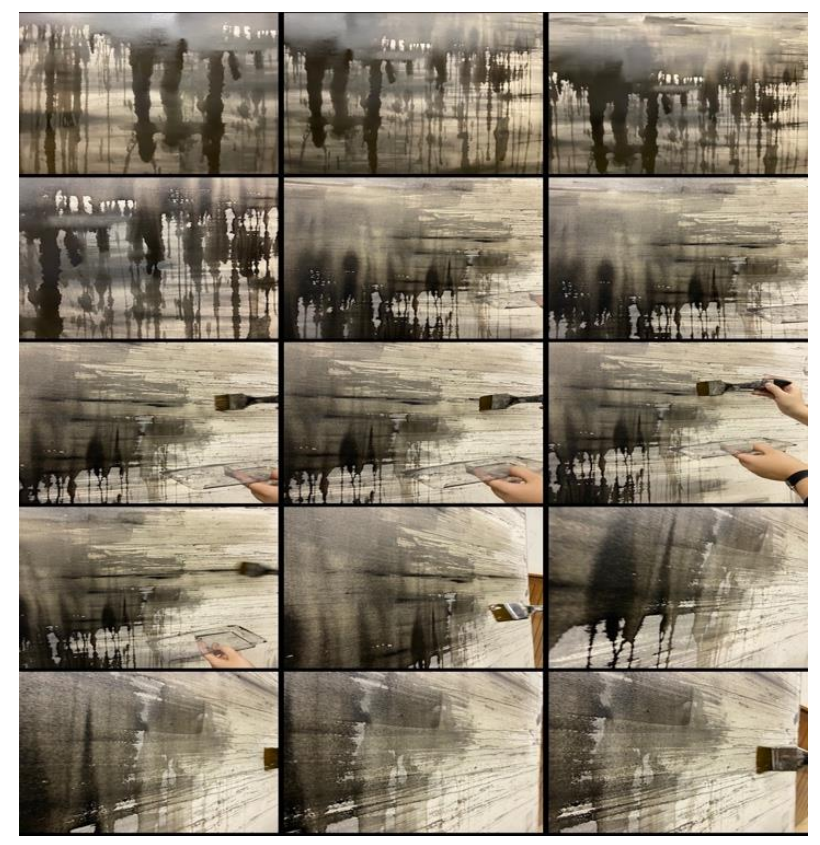

Figure 2: Derivative stratigraphy, 2020 (by author).

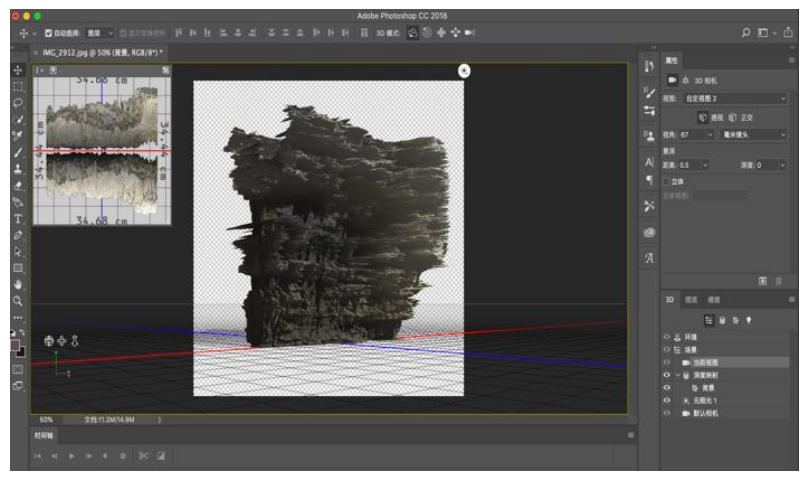

Figure 3: Use Adobe Photoshop for digital image conversion (by author).

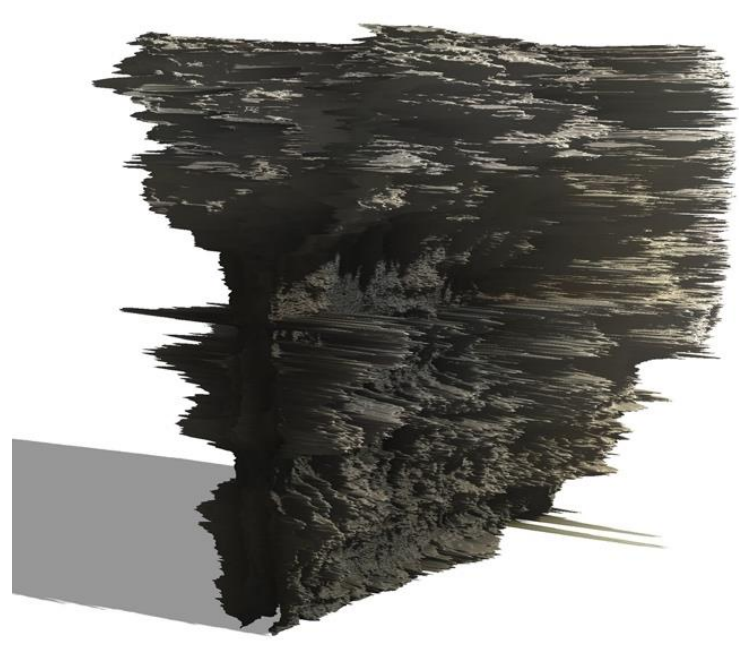

Figure 4: Derivative stratigraphy, 2020 (by author).

The painting is converted through digital technology, and finally a digital image is formed as part of the virtual stratigraphy series.

\section{REFERENCES}

Buchanan, I., \& Swiboda, M. (2006) Deleuze and music. Edinburgh: Edinburgh University Press.

Renfrew, C., \& Bahn, P. G. (2013) Archaeology: the key concepts. London: Routledge, Taylor \& Francis Group, September.

Rockmore, T. (1999) Dufrenne, Humanism, and Anti-humanism. Journal of French and Francophone Philosophy, 11(1), 72-83. doi: 10.5195/jffp. 1999.152 